\title{
THE IMPACT OF THE SOIL CONDITIONER UGMAX ON SELECTED QUALITATIVE CHARACTERISTICS OF POTATO TUBERS
}

\author{
ZARZECKA, K. ${ }^{1}$ - GugAŁA, M. ${ }^{1}-$ SiKorsKa, A. ${ }^{2 *}-$ MystKowsKA, I. ${ }^{3}$ \\ ${ }^{I}$ Department of Agrotechnology, University of Natural Sciences and Humanities \\ Prusa 14, 08-110 Siedlce, Poland \\ (e-mail:kzarzecka@uph.edu.pl; gugala@uph.edu.pl) \\ ${ }^{2}$ Department of Agriculture, The State Higher School of Vocational Education in Ciechanów \\ Narutowicza 9, 06-400 Ciechanów, Poland \\ (e-mail: aniasikorska6@wp.pl) \\ ${ }^{3}$ State School of Higher Education \\ Sidorska 95/97, 21-500 Biata Podlaska, Poland \\ (e-mail: imystkowska@op.pl) \\ *Corresponding author \\ e-mail: aniasikorska6@wp.pl
}

(Received $9^{\text {th }}$ Mar 2017; accepted $8^{\text {th }}$ Nov 2017)

\begin{abstract}
A field experiment was carried out in 2008-2010 on soil of a very good rye complex. The soil reaction ranged from slightly acidic to acidic $(\mathrm{pH}$ in $1 \mathrm{n} \mathrm{KCl}$ was 4.81-5.91), and the soil was very suitable for potato cultivation. The experiment was arranged as a two-factorial split-plot design with three replicates. The trial included the following two factors: I - two edible potato cultivars (Satina and Tajfun), II - five UGmax application methods (1. control without UGmax, 2. UGmax applied prior to tuber planting at the rate of $1.0 \mathrm{dm}^{3} \mathrm{ha}^{-1}, 3$. UGmax applied prior to tuber planting at the rate of $0.5 \mathrm{dm}^{3}$ $\mathrm{ha}^{-1}$ followed by two foliar applications at the rate of $0.25 \mathrm{dm}^{3} \mathrm{ha}^{-1}, 4$. UGmax applied prior to tuber planting at the rate of $1.0 \mathrm{dm}^{3} \mathrm{ha}^{-1}$ followed by two foliar applications at the rate of $0.5 \mathrm{dm}^{3} \mathrm{ha}^{-1}, 5$. two foliar applications of UGmax at the rate of $0.5 \mathrm{dm}^{3} \mathrm{ha}^{-1}$ ). Random tuber samples from 10 plants were collected in each plot, and used to conduct chemical analysis and assess tuber consumption-related characteristics. The soil conditioner UGmax beneficially affected tuber content of starch and vitamin C, and slightly enhanced after-cooking darkening compared with control tubers. Weather conditions in the study years significantly affected dry matter, starch, and vitamin C content as well as raw flesh darkening and after-cooking darkening of tubers. Under the weather conditions in 2010, when precipitation was abundant, the contents of the components studied were the lowest but raw flesh darkening and aftercooking darkening were more intense due to a higher accumulation of reducing sugars.
\end{abstract}

Keywords: table potato, dry matter, starch, vitamin C, consumption-related characteristics

\section{Introduction}

Intensification of crop production (cultivation in monoculture, reduced soil tillage, declining soil content of humus, an application of plant protection chemicals, use of heavy machinery) and livestock production (declining farmyard manure supply due to animal facility modernisation) results in a microorganism- and soil fauna-impoverished environment, as well as exacerbating physical, chemical and microbiological properties of the soil, which in turn affects both plant yields and yield quality (Melero et al., 2006; Trawczyński and Bogdanowicz, 2007; Mrówczyński and Roth, 2009; Liu et al., 2010). The negative effect of the aforementioned factors becomes even more pronounced due to unfavourable weather conditions during the growing season, and agrotechnological 
mistakes. Thus, farmers are more and more interested in various types of commercially available biostimulants, extracts, bacterial vaccines, EM (effective microorganisms) products, biofertilisers and conditioners which enhance soil humus and organic carbon, increase soil $\mathrm{pH}$, improve plant resistance to diseases and other stress conditions, contribute to better nutrient uptake from the soil, and increase plant yields (Emitazi et. al., 2004; Boligłowa and Gleń, 2008; Sulewska et al., 2009; Piotrowska et al., 2012; Zarzecka et al., 2014).

Organic matter content is a basic indicator of soil quality and fertility, and a key factor in proper plant growth, development and yield performance (Haynes, 2005; Lal, 2011; Krasowicz et al., 2011). The soil conditioner UGmax, one of products applied in plant cultivation, is a natural liquid concentrate containing beneficial microorganisms such as lactic acid bacteria, photosynthetic bacteria, Azotobacter, Pseudomonas, yeast, actinomycetes as well as some macroelements and microelements (Trawczyński and Bogdanowicz, 2007). Results of research into the effect of this product are sometimes equivocal, however. Several workers have not confirmed a positive influence of UGmax (Kaczmarek et al., 2008; Dinesh et al., 2010; Martyniuk, 2011); others have reported a beneficial effect of this conditioner (Sulewska et al., 2009; Ratajczak et al., 2016). Piotrowska et al. $(2010,2012)$ found that Ugmax application increased soil $\mathrm{pH}$, organic carbon $\left(\mathrm{C}_{\text {org }}\right)$ content, total nitrogen content, and soil enzymic activity compared with control. In contrast, a study by Dębska et al. (2016) established an increase in soil organic carbon content and organic matter, including humins and humic acids. Many authors applied UGmax and observed a tendency for crop yields to increase, or a beneficial influence on crop yield chemical composition and increased plant resistance to diseases. Sulewska et al. (2009) reported that the yield of maize cultivated for grain and silage increased by 0.71 and $5.6 \mathrm{t} \cdot \mathrm{ha}^{-1}$, respectively, compared with control. Kotwica et al. (2013) noticed an increase in winter wheat biomass and grain yield whereas Górski et al. (2015) pointed to enhanced sugar content in sugar beet roots and higher root yield. Kołodziejczyk et al. (2013) reported an increase in spring wheat grain yield and Keutgen et al. (2014) found that the quality of carrot storage roots improved due to increased total carotenoids and lower ascorbic acid losses during processing. In their study on potato, Trawczyński and Bogdanowicz (2007) recorded total tuber yield that increased by $7.1 \%$, Jabłoński (2012) reported that the total yield and marketable yield were higher by 12.2 and 15.1\%, respectively, and Frąckowiak-Pawlak (2011), who conducted a six-year study, found a 30\% increase in tuber yield. Kołodziejczyk (2014a) pointed to a favourable effect of UGmax on tuber yield and yield components, and in another study, the author noted a positive effect of the product on tuber fresh and dry matter yields as well as plant dry matter yield. Kowalska (2016) reported an increase in table potato tuber yield, a higher share of these tubers in the total yield, and reduction of Phytophthora infestans symptoms on the plant. Zarzecka et al. (2011) demonstrated that an application of UGmax contributed to an increase in tuber yield and a decline in the share of tubers with Streptomyces scabies and Rizoctonia solani symptoms. In other study with UGmax, Zarzecka et al. (2014) recorded increased nitrogen and magnesium amounts in potato tubers compared with control. UGmax is a well-established product which is popular with farmers as it improves soil properties, boosts crop yields and is cost-effective (Trawczyński and Bogdanowicz, 2007; Piotrowska et al., 2012). There are few studies examining the effect of the soil conditioner UGmax on tuber chemical composition and consumption-related characteristics. Moreover, the reports that exist are unequivocal. Thus, more research 
into UGmax application in potato cultivation is fully justifiable. Potatoes are a major staple food and, as a result, are one of the most important crop plants in the world, Europe and Poland (Lisińska et al., 2009; Abolgasem, 2014; Wegener et al., 2015). Potato consumption in Poland is quite high and has amounted to 100-121 kg per capita in the last decade (Dzwonkowski et al., 2016). Hence, the objective of the study reported here was to determine the effect of the soil conditioner UGmax on selected qualitative characteristics of table potato tubers.

\section{Materials and methods}

\section{The experimental site}

A three-year field trial was conducted at the Zawady Experimental Farm $\left(52^{\circ} 20^{\prime} \mathrm{N}\right.$; $22^{\circ} 30^{\prime}$ ) on grey brown podzolic soil representing the very good rye class of agricultural land suitability (class IVa). The soil ranged from slightly acidic to acidic (4.81-5.91, pH in $1 \mathrm{n} \mathrm{KCl}$ ), had high to very high available phosphorus content, low to high potassium content, and low to average magnesium content. The experiment was a split-plot arrangement with three replicates. Factor I included two medium-early table potato cultivars: Satina and Tajfun - high-yielding varieties characterised by consumption characteristics that are significant for customers, which makes them popular on the market and hence in production in east-central Poland. Moreover, in the study years, they were included in the List of Recommended Cultivars for Mazovian Voivodeship based on research of Post-Registration Variety Testing. Factor II consisted of five application methods of the soil conditioner UGmax presented in Table 1.

Table 1. The use of UGmax in the experiment

\begin{tabular}{|c|c|c|c|c|}
\hline \multirow[b]{2}{*}{ Treatments } & \multirow{2}{*}{$\begin{array}{c}\text { Rates } \\
\left(\mathbf{d m}^{3} \cdot \mathbf{h a}^{-1}\right)\end{array}$} & \multicolumn{3}{|c|}{ Application dates of UGmax } \\
\hline & & $\begin{array}{l}\text { Before tuber } \\
\text { planting }\end{array}$ & $\begin{array}{l}10-15 \mathrm{~cm} \text { potato } \\
\text { plant height }\end{array}$ & Flowering \\
\hline 1. Control-without UGmax & - & - & - & - \\
\hline 2. UGmax - before planting & 1.0 & 1.0 & - & - \\
\hline $\begin{array}{l}\text { 3. UGmax - before planting and } \\
\text { double foliar application }\end{array}$ & 1.0 & 0.5 & 0.25 & 0.25 \\
\hline $\begin{array}{l}\text { 4. UGmax - before planting and } \\
\text { double foliar application }\end{array}$ & 2.0 & 1.0 & 0.5 & 0.5 \\
\hline 5. UGmax - double foliar treatment & 1.0 & - & 0.5 & 0.5 \\
\hline
\end{tabular}

The conditioner was dissolved in $300 \mathrm{dm}^{3} \cdot$ water per $\mathrm{ha}^{-1}$. The product contained the following macroelements and microelements: $1200 \mathrm{~N}, 220 \mathrm{P}, 2905 \mathrm{~K}, 100 \mathrm{Mg}, 200 \mathrm{Na}$, $0.3 \mathrm{Mn}$, and the following microorganisms: lactic acid bacteria, photosynthetic bacteria, Azotobacter, Pseudomonas, yeast and actinomycetes. In autumn, farmyard manure was applied at a rate of $25.0 \mathrm{t} \cdot \mathrm{ha}^{-1}$ in addition to mineral fertilisers used at the following rates: $44.0 \mathrm{~kg} \cdot \mathrm{ha}^{-1} \mathrm{P}$ (in the form of $46 \%$ triple superphosphate), $124.5 \mathrm{~kg} \cdot \mathrm{ha}^{-1} \mathrm{~K}$ (in the form of $60 \%$ potassium salt) and $100 \mathrm{~kg} \mathrm{~N}$ per 1 ha (in the form of $34 \%$ ammonium saltpeter), nitrogen applied in spring. Potatoes were planted at $67.5 \times 37 \mathrm{~cm}$ spacing in mid-April and harvested in September. To control weeds, a mixture of the herbicides Command $480 \mathrm{SC} 0.2 \mathrm{dm}^{3} \cdot \mathrm{ha}^{-1}+$ Afalon Dyspersyjny $450 \mathrm{SC} 1.0 \mathrm{dm}^{3} \cdot \mathrm{ha}^{-1}$ was applied 
5-7 days prior to potato plant emergence. Potato blight was controlled using Ridomil Gold MZ 68 WG and Dithane 455 SC and Colorado potato beetle was controlled by means of Apacz $50 \mathrm{WG}$ and Actara $25 \mathrm{WG}$. Prior to harvest, random samples of tubers were collected from each plot and used for chemical analysis and assessment of consumption-related characteristics of the tubers.

\section{Chemical analysis methods}

Vitamin C content was determined by means of Tillman's method as modified by Pijanowski (Rutkowska, 1981). The dry matter content of potatoes was determined by drying to constant weight at $105^{\circ} \mathrm{C}$, and starch concentration using a Reimann hydrostatic balance. The assessment of consumption-related (organoleptic) tuber characteristics was performed 8-10 days after harvest by a team which consisted of four people. The darkening of raw flesh was evaluated subjectively on ten tubers collected from each treatment, 10 min after cutting, and darkening of cooked flesh 10 min after cooking, using a Danish colour scale on which 1 - most intense darkening, and 9 unchanged colour (Roztropowicz, 1999). All the analyses were performed at the Chemical Laboratory of the Department of Agrotechnology of Siedlce University of Natural Sciences and Humanities.

\section{Meteorological conditions}

The weather conditions in the study years varied (Table 2). In 2008, air temperature was similar to the long-term mean whereas precipitation was by $96.2 \mathrm{~mm}$ higher but unevenly distributed throughout the growing season. The year was conducive to potato plant growth, development and yielding. In 2009, the average temperature was higher than the mean calculated across 1987-2000 and precipitation was unevenly distributed. The year 2010 was warmer than the previous years, and wet because of heavy precipitation which exceeded the average long-term sum by $184.5 \mathrm{~mm}$.

Table 2. Air temperature and rainfall during potato growing seasons according to the Zawady Meteorological Station

\begin{tabular}{|c|c|c|c|c|c|c|c|c|c|}
\hline \multirow{3}{*}{ Months } & \multicolumn{4}{|c|}{ Air temperature $\left({ }^{\circ} \mathbf{C}\right)$} & \multicolumn{4}{c|}{ Rainfall (mm) } \\
\cline { 2 - 9 } & Long-term mean & \multicolumn{2}{|c|}{ Monthly means } & Long-term mean & \multicolumn{3}{|c|}{ Monthly sums } \\
\cline { 2 - 10 } & $\mathbf{1 9 8 7 - 2 0 0 0}$ & $\mathbf{2 0 0 8}$ & $\mathbf{2 0 0 9}$ & $\mathbf{2 0 1 0}$ & $\mathbf{1 9 8 7 - 2 0 0 0}$ & $\mathbf{2 0 0 8}$ & $\mathbf{2 0 0 9}$ & $\mathbf{2 0 1 0}$ \\
\hline April & 7.8 & 9.1 & 10.3 & 8.9 & 38.6 & 28.2 & 8.1 & 10.7 \\
May & 12.5 & 12.7 & 12.9 & 14 & 44.1 & 85.6 & 68.9 & 93.2 \\
June & 17.2 & 17.4 & 15.7 & 17.4 & 52.4 & 49 & 145.2 & 62.6 \\
July & 19.2 & 18.4 & 19.4 & 21.6 & 49.8 & 69.8 & 26.4 & 77 \\
August & 18.5 & 18.5 & 17.7 & 19.8 & 43 & 75.4 & 80.9 & 106.3 \\
September & 13.1 & 12.2 & 14.6 & 11.8 & 47.3 & 63.4 & 24.9 & 109.9 \\
\hline \multirow{2}{*}{ April-September } & 14.7 & 14.7 & 15.1 & 15.6 & 275.2 & 371.4 & 354.4 & 459.7 \\
& mean & & & & sum & & & \\
\hline
\end{tabular}

\section{Statistical analysis}

Results of the study were analysed by ANOVA. Significance of sources of variation was checked with the Fisher-Snedecor test and the significance of differences between 
means was tested using the multiple comparison Tukey's test at the significance level of $\mathrm{P}=0.05$. Statistical calculations were performed in Excel using the authors' own algorithm based on the split-plot mathematical model.

\section{Results}

The dry matter content of potato cultivated in the experiment reported here ranged from 184.5 to $238.9 \mathrm{~g} \cdot \mathrm{kg}^{-1}$ and was significantly affected by cultivars and weather conditions in the study years (Tables 3, 6). Significantly higher dry matter amounts were accumulated by Tajfun vs Satina, and the most favourable years for dry matter accumulation were 2009 and 2008. In these study years, temperatures throughout the months of the greatest yield production (July, August and September) which are the most conducive to dry matter accumulation were the closest to the long-term mean. The research reported here demonstrated that UGmax application, regardless of the treatment, did not significantly affect the tuber content of dry matter. However, there was observed a tendency for the amount of this component to increase compared with control.

Table 3. The dry matter content and starch in potato tubers $\left(\mathrm{g} \cdot \mathrm{kg}^{-1}\right)$

\begin{tabular}{|c|c|c|c|c|c|c|}
\hline \multirow{3}{*}{ Treatments } & \multicolumn{3}{|c|}{ Dry matter } & \multicolumn{3}{|c|}{ Starch } \\
\hline & \multicolumn{2}{|c|}{ Cultivars } & \multirow{2}{*}{ Mean } & \multicolumn{2}{|c|}{ Cultivars } & \multirow{2}{*}{ Mean } \\
\hline & Satina & Tajfun & & Satina & Tajfun & \\
\hline 1 & 184.5 & 231.1 & 207.8 & 127 & 156.1 & 141.6 \\
\hline 2 & 190 & 236.7 & 213.4 & 128.1 & 157 & 142.6 \\
\hline 3 & 190.5 & 233.9 & 212.2 & 127.4 & 156.6 & 142 \\
\hline 4 & 194.2 & 238.9 & 216.6 & 130 & 159.5 & 144.8 \\
\hline 5 & 192.8 & 232.8 & 212.8 & 128.2 & 158.9 & 143.6 \\
\hline Mean & 190.4 & 234.7 & 212.6 & 128.2 & 157.6 & 142.9 \\
\hline Mean for treatments 2-5 & 191.9 & 235.6 & 213.8 & 128.4 & 158 & 143.2 \\
\hline \multicolumn{7}{|l|}{$\mathrm{LSD}_{0.05}$ for: } \\
\hline Cultivars & & & 3.1 & & & 1.8 \\
\hline Treatments & & & n.s. & & & 3 \\
\hline Interaction cultivars $\mathrm{x}$ tre & ments & & n.s. & & & n.s. \\
\hline
\end{tabular}

n.s. - non-significant differences

Starch content in tubers depended on the cultivar, UGmax application methods and weather conditions during the experimental period, and ranged from 127.0 to 159.5 $\mathrm{g} \cdot \mathrm{kg}^{-1}$ (Tables 3, 6). Tajfun rather than Satina accumulated more starch. UGmax application positively influenced starch accumulation, the most starch being accumulated by potatoes which had been sprayed with the conditioner three times at the total rate of $2.0 \mathrm{dm}^{3} \cdot \mathrm{ha}^{-1}$.

Analysis of an accumulation of this basic carbohydrate in individual growing seasons revealed that the most starch was accumulated in 2009, the accumulation being significantly lower in the remaining study years. 
Vitamin C content in potato tubers ranged from 195.6 to $234.8 \mathrm{mg} \cdot \mathrm{kg}^{-1}$ fresh matter and was affected by UGmax application and weather conditions in the study years (Tables 4, 6). The cultivars studied had a similar vitamin $\mathrm{C}$ content. In the present study, vitamin $\mathrm{C}$ accumulation was significantly higher in tubers harvested in plots where UGmax had been applied three times (prior to tuber planting, when plants were 10-15 $\mathrm{cm}$ high, and at the beginning of bloom time) compared with control. They found a significant effect of atmospheric conditions in the study years on vitamin $\mathrm{C}$ content. The highest concentration of this component was determined in 2008 when the air temperature was similar to the long-term mean and precipitation was evenly distributed compared with 2009 and 2010.

Table 4. The vitamin C content in potato tubers ( $\mathrm{mg} \mathrm{kg}^{-1}$ fresh matter)

\begin{tabular}{|c|c|c|c|}
\hline \multirow{2}{*}{ Treatments } & \multicolumn{2}{|c|}{ Cultivars } & \multirow{2}{*}{ Mean } \\
\cline { 2 - 4 } & Satina & Tajfun & 210.6 \\
2 & 209.6 & 211.7 & 214.1 \\
3 & 212.4 & 215.7 & 215.9 \\
4 & 214.7 & 217 & 218.2 \\
5 & 217.7 & 218.6 & 213.3 \\
\hline Mean & 211.8 & 214.8 & 214.4 \\
\hline Mean for 2-5 objects & 213.2 & 215.5 & 215.4 \\
\hline LSD & 214.2 & 216.5 & n.s. \\
Cultivars for: & & & 3.9 \\
Treatments & & n.s. \\
Interaction cultivars $x$ treatments & & \\
\hline
\end{tabular}

n.s. - non-significant differences

The most important characteristics of table potato consumptionrelated/organoleptic/sensory value include: raw tuber flesh darkening, after-cooking darkening, flavour and culinary type. In the study reported here, raw tuber flesh darkening, assessed 10 min after tubers were cut through, was significantly affected by cultivars and weather conditions in the study years (Tables 5, 6). Satina darkened less than Tajfun, the darkening for both cultivars being low as it averaged 8.89 and 8.87, respectively, on a 1-9 scale. Analysis of the effect of weather conditions on raw tuber flesh darkening demonstrated that it was the highest in 2010 , when precipitation was high, and the lowest in the 2008 growing season.

Organoleptic testing of cooked tubers demonstrated a significant effect of UGmax application methods and weather conditions throughout the study years on this characteristic (Tables 5, 6). An application of the conditioner contributed to an increase in after-cooking darkening of tubers harvested in the plots where UGmax had been applied two and three times (treatment 3, 4 and 5). The change in colour was inconsiderable as after-cooking darkening did not exceed 0.1 point on a 1-9 scale. Under the climatic conditions which prevailed in 2010, after cooking darkening of tubers was significantly higher compared with the remaining study years, which indicates that excessive precipitation during the growing season has a negative effect of this attribute. 
Table 5. Darkening of raw flesh and cooked flesh of potato tubers after $10 \mathrm{~min}$ (scale 1-9)

\begin{tabular}{|c|c|c|c|c|c|c|}
\hline \multirow{3}{*}{ Treatments } & \multicolumn{3}{|c|}{ Raw flesh darkening } & \multicolumn{3}{|c|}{ After-cooking darkening } \\
\hline & \multicolumn{2}{|c|}{ Cultivars } & \multirow{2}{*}{ Mean } & \multicolumn{2}{|c|}{ Cultivars } & \multirow{2}{*}{ Mean } \\
\hline & Satina & Tajfun & & Satina & Tajfun & \\
\hline 1 & 8.91 & 8.89 & 8.9 & 8.98 & 8.94 & 8.96 \\
\hline 2 & 8.91 & 8.89 & 8.9 & 8.92 & 8.9 & 8.92 \\
\hline 3 & 8.88 & 8.87 & 8.87 & 8.89 & 8.87 & 8.88 \\
\hline 4 & 8.88 & 8.88 & 8.88 & 8.89 & 8.88 & 8.89 \\
\hline 5 & 8.89 & 8.85 & 8.86 & 8.87 & 8.87 & 8.87 \\
\hline Mean & 8.89 & 8.87 & 8.88 & 8.91 & 8.89 & 8.9 \\
\hline $\begin{array}{c}\text { Mean for treatments 2- } \\
5\end{array}$ & 8.89 & 8.87 & 8.88 & 8.89 & 8.88 & 8.89 \\
\hline \multicolumn{4}{|l|}{$\mathrm{LSD}_{0.05}$ - for: } & & & \\
\hline \multicolumn{3}{|l|}{ Cultivars } & 0.02 & & & n.s. \\
\hline \multicolumn{3}{|l|}{ Treatments } & n.s. & & & 0.05 \\
\hline \multicolumn{3}{|c|}{ Interaction cultivars $\mathrm{x}$ treatments } & n.s. & & & n.s. \\
\hline
\end{tabular}

n.s. - non-significant differences

Table 6. Effect of study years on the content of dry matter, starch and vitamin C, and flesh darkening of potato tubers

\begin{tabular}{|c|c|c|c|c|c|}
\hline \multirow{2}{*}{ Years } & \multirow{2}{*}{ Dry matter $\left(\mathrm{g} \cdot \mathrm{kg}^{-1}\right)$} & \multirow{2}{*}{$\operatorname{Starch}\left(g \cdot \mathrm{kg}^{-1}\right)$} & \multirow{2}{*}{ Vitamin C (mg $\left.\cdot \mathrm{kg}^{-1} \mathbf{f} . \mathrm{m}.\right)$} & \multicolumn{2}{|c|}{ Flesh darkening (scale 1-9) } \\
\hline & & & & Raw & Cooked \\
\hline 2008 & 220.5 & 142.6 & 234.8 & 9 & 8.99 \\
\hline 2009 & 221.2 & 151.8 & 212.8 & 8.87 & 8.94 \\
\hline 2010 & 196 & 134.3 & 195.6 & 8.78 & 8.78 \\
\hline Mean & 212.6 & 142.9 & 214.4 & 8.88 & 8.9 \\
\hline $\mathrm{LSD}_{0.05}$ & 0.5 & 0.3 & 4.4 & 0.03 & 0.06 \\
\hline
\end{tabular}

\section{Discussion}

Potato nutritional value is mainly related to tuber chemical composition, in particular dry matter content, starch content, total sugars, reducing sugars, protein content, vitamin C content, minerals and harmful substances (Lisińska et al., 2009; Leszczyński, 2012; Zarzecka et al., 2013; Sawicka et al., 2015). The majority of traits which are significant in potato production are dependent on the genotype, agrotechnological practices and meteorological conditions, in particular precipitation and air temperature during the growing season (Sawicka, 2000; Mazurczyk and Lis, 2001; Leszczyński, 2012; Kołodziejczyk, 2014a; Zarzecka et al., 2014).

In the study reported here, dry matter content in potato tubers was significantly affected by the cultivar and weather conditions. Of the cultivars examined, cv. Tajfun accumulated more dry matter than Satina. Moreover, 2009 and 2008, when temperatures in the months of yield formation were similar to the long-term mean, were the most conducive to the accumulation of this component. A similar effect of cultivars and weather conditions during the growing season on dry matter content was reported by Sawicka and Mikos-Bielak (2008) and Sawicka and Pszczółkowski (2005). Also 
Mazurczyk and Lis (2001), Trawczyński and Prokop (2016) found that potato tubers accumulated the most dry matter and starch under favourable hydrothermal conditions.

The research reported here demonstrated that UGmax application, regardless of the treatment, did not significantly affect the tuber content of dry matter. However, there was observed a tendency for the amount of this component to increase compared with control. An insignificant effect of UGmax was also noted by Kołodziejczyk (2016) whereas Trawczyński and Bogdanowicz (2007) reported a statistically significant increase in dry matter content following an application of the conditioner.

Starch is the main component of potato tuber dry matter, and starch content in cultivars registered in Poland ranges from 11.0 to $18.3 \%$. In the study discussed here, the tuber content of starch was significantly affected by cultivars, methods of UGmax application and climatic conditions in the study years. Similarly to dry matter, starch content was higher in Tajfun than Satina. Soil conditioner application significantly improved potato quality as it contributed to an increase in the tuber content of starch. An increase in starch content following UGmax application when accompanied by full mineral fertilisation, compared with control, was also recorded by Szewczuk et al. (2016) and Kołodziejczyk (2016). In turn, Trawczyński and Bogdanowicz (2007) demonstrated no changes in starch content due to an application of the conditioner. Analysis of starch content in individual growing seasons demonstrated that more starch was accumulated in tubers in 2009 when air temperatures were similar to the long-term mean. Starch accumulation was the lowest in 2010 when precipitation was high during the growing season. Puła and Skowera (2004) demonstrated that high precipitation was a factor which significantly reduced starch accumulation in tubers. Many authors have reported that starch content in potato tubers is affected by the genetic factor and weather conditions (Sawicka and Mikos-Bielak, 2008; Lisińska et al., 2009; Abolgasem, 2014; Kołodziejczyk, 2016; Trawczyński and Prokop, 2016).

In order to function properly, the human body needs vitamins in addition to carbohydrates, proteins, fats and minerals. Potato tubers are high in vitamin $\mathrm{C}$. The vitamin is one of major anti-oxidants which also participates in many processes and metabolic conversions. Moreover, as it is not synthesised by the human body so the vitamin has to be provided in the diet (Lisińska et al., 2009; Leszczyński, 2012).

In the present study, vitamin $C$ content was significantly affected by an application of UGmax and weather conditions over the experimental period. In contrast, the cultivars studied differed insignificantly in terms of the characteristic in question. In turn, Sawicka et al. (2014) demonstrated that vitamin C content was more affected by genotype than the environment. An application of UGmax positively affected an accumulation of vitamin $\mathrm{C}$ in potato tubers. An increase in vitamin $\mathrm{C}$ content following UGmax application was reported by Wichrowska et al. (2015) who examined potato tubers, and by Keutgen et al. (2014) who studied carrot storage roots. Chemical analyses conducted in the study reported here revealed the highest vitamin $\mathrm{C}$ content in tubers harvested under the optimum weather conditions of 2008, compared with the remaining years. Similar results were obtained by Mazurczyk and Lis (2001) and Trawczyński and Prokop (2016).

The following attributes determine the sensory quality of table potato tubers: raw tuber flesh darkening, after-cooking darkening, flavour and culinary type (Lisińska et al., 2009; Leszczyński, 2012). In the study reported here, raw flesh darkening was significantly affected by the cultivar and weather conditions whereas after-cooking darkening was significantly influenced by UGmax application and climatic conditions 
in the study years. Differences in raw flesh darkening as affected by cultivar properties were also reported by Sawicka (2000). Raw tuber flesh of potatoes cultivated in 2010, characterised by high precipitation, was the most prone to darkening compared with 2008 and 2009. Also Sawicka (2000) noticed that sunny and dry weather was associated with slight darkening of raw tuber flesh. In contrast, Kołodziejczyk (2016) reported no effect of hydrothermal conditions on raw flesh darkening. Moreover, the author found no influence of UGmax on raw tuber flesh darkening, which agrees with the findings reported here.

After-cooking darkening is a very important attribute for consumers (Leszczyński, 2012). Organoleptic assessment of cooked tubers revealed that UGmax increased aftercooking darkening. Differences in the assessment of flesh darkening ranged from 0.02 to 0.09 points on a scale of $1-9$, the control being the most favourable in this respect. The available literature lacks reports on the effect of UGmax on after-cooking darkening of potato tubers. Potatoes grown in 2008, characterised by hot summer, had the lowest after-cooking darkening, it being the highest in the wet 2010 . Too much rain increased flesh darkening due to an increased accumulation of reducing sugars in potato tubers. A similar finding was reported by Grudzińska and Zgórska (2008) who noted that a decline in the potato tuber content of starch was followed by an increase reducing sugars, the changes being the result of starch transformation into simple sugars.

\section{Conclusions}

The study demonstrated that the soil conditioner UGmax applied to potatoes had a positive effect on starch content and vitamin $\mathrm{C}$ content in their tubers, and slightly increased after cooking darkening compared with control tubers where no UGmax had been applied. The cultivar factor significantly affected the attributes tested. Weather conditions during the period of Solanum tuberosum growth and development had a significant effect on dry matter, starch and vitamin $\mathrm{C}$ content in tubers as well as raw flesh darkening and after-cooking darkening. In 2010, the concentration of the components examined was lower but potato tuber flesh darkening was more intense due to excessive precipitation, because of an increased accumulation of reducing sugars whose concentration increases as starch content declines.

Acknowledgements. The results of the research carried out under the research theme No. 214/04/S were financed from the science grant granted by the Ministry of Science and Higher Education.

\section{REFERENCES}

[1] Abolgasem, T. (2014): Effect of variety, fertilisation, rotation, crop protection and growing season on yield and nutritional quality of potato (Solanum tuberosum L.). Doctoral dissertation, Faculty of Science, Agriculture and Engineering, Newcastle University, United Kingdom.

[2] Boligłowa, E., Gleń, K. (2008): Assessment of effective microorganism activity (EM) in winter wheat protection against fungal diseases. - Ecol. Chem. Eng. 15(1-2): 23-27.

[3] Dębska, B., Długosz, J., Piotrowska-Długosz, A., Banach-Szott, M. (2016): The impact of a bio-fertilizer on the soil organic matter status and carbon sequestration - results from a field-scale study. - J. Soils Sediments 16: 2335-2343. 
[4] Dinesh, R., Srinivasan, V., Hamza, S., Manjusha, A. (2010): Short-term incorporation of organic manures and biofertilizers influences biochemical and microbial characteristics of soils under an annual crop [Turmeric (Curcuma longa L.)]. - Bioresour. Technol. 101: 4697-4702.

[5] Dzwonkowski, W., Szczepaniak, I., Zdziarska, T., Mieczkowski M. (2016): Potato's market. State and perspectives. - Wyd. IERiGŻ-PIB, ARR, MRiRW, Warszawa 43: 2128.

[6] Emitazi, G., Nader, A., Etemadifar, Z. (2004): Effect of nitrogen fixing bacteria on growth of potato tubers. - Adv. Food Sci. 26(2): 56-58.

[7] Frąckowiak-Pawlak, K. (2011): The results of many years of experience with UGmax. PoradnikGospodarski 2: 11.

[8] Górski, D., Gaj, R., Piszczek, J., Ulatowska A. (2015): Impact of soil fertilizer UGmax on leaf infection degree by leaf spot disease (Cercosporabeticola Sacc.) and yield and root quality of sugar beet. - Prog. Plant Prot. 55(2): 195-201.

[9] Grudzińska, M., Zgórska K. (2008): Effect of sugar content in potato tubers on colour of chips. - Żywność Nauka Technologia Jakość 5: 107-115.

[10] Haynes, R. J. (2005): Labile organic matter fractions as central components of the quality of agricultural soils: an overview. - Adv. Agron. 85: 221-268.

[11] Jabłoński, K. (2012): Modern potato production in integrated sustainable agriculture. Technika Rolnicza Ogrodnicza Leśna 2: 1-4.

[12] Kaczmarek, Z., Jakubus, M., Grzelak, M., Mrugalska, L. (2008): Impact of the addition of various doses of effective microorganisms to arable-humus horizons of mineral soils on their physical and water properties. - J. Res. Appl. Agric. Engin. 53(3): 118-121.

[13] Keutgen, A. J., Wszelaczyńska, E., Pobereżny, J. (2014): Influence of cultivar and UGmax on antioxidative properties of carrot roots (Daucuscarota L.) and their stability during freezing process. - Environ. Prot. Natural Res. 25(4): 19-22.

[14] Kołodziejczyk, M. (2014a): Effect of nitrogen fertilization and microbial preparations on potato yielding. - Plant Soil Environ. 60(8): 379-386.

[15] Kołodziejczyk, M. (2014b): Effectiveness of nitrogen fertilization and application of microbial preparations in potato cultivation. - Turkish J. Agric. Forestry 38: 299-310.

[16] Kołodziejczyk, M. (2016): Effect of nitrogen fertilization and microbial preparations on quality and storage losses in edible potato. - Acta Agrophys. 23(1): 67-78.

[17] Kołodziejczyk, M., Kulig, B., Oleksy, A., Szmigiel, A. (2013): The effectiveness of Nfertilization and microbial preparation on spring wheat. - Plant Soil Environ. 59(8): 335341.

[18] Kotwica, K., Jaskulska, I., Piekarczyk, M., Wasilewski, P., Gałęzewski, L., Kulpa, D. (2013): Effect of soil conditioning and the application of biostimulants on the productivity of winter wheat in crop rotation and short-term monoculture. - Fragm. Agron. 30(4): 55-64.

[19] Kowalska, J. (2016): Effect of fertilization and microbiological bio-stimulators on healthiness and yield of organic potato. - Prog. Plant Prot. 56(2): 230-235.

[20] Krasowicz, S., Oleszek, W., Horabik, J., Debicki, R., Jankowiak, J., Styczyński, T., Jadczyszyn, J. (2011): Rational management of the soil environment in Poland. - Pol. J. Agron. 7: 43-58.

[21] Lal, R. (2011): Sequestering carbon in soils of agro-ecosystems. - Food Policy 36: 533539.

[22] Leszczyński, W. (2012): Nutrition value of potato and potato products (Review of literature). - Biuletyn Instytutu Hodowli i Aklimatyzacji Roślin 266: 5-20.

[23] Lisińska, G., Pęksa, A., Kita, A., Rytel, E., Tajner-Czopek, A. (2009): The quality of potato for processing and consumption. - Food 3(Special Issue 2): 99-104.

[24] Liu, E., Yan, C., Mei, X., He, W., Bing, S. H., Ding, L., Liu, Q., Liu, S., Fan, T. (2010): Long-term effects of chemical fertilizers, straw, and manure on soil chemical and biological properties in northwest China. - Geoderma 158: 173-180. 
[25] Martyniuk, S. (2011): Effective and ineffective microbial preparations used in plant protection and production and methods of their evaluation. - Post. Mikrobiol. 50(4): 321328.

[26] Mazurczyk, W. Lis, B. (2001): Variation of chemical composition of tubers of potato table cultivars grown under deficit and excess water. - Pol. J. Environ. Stud. 10/51(2): 27-30.

[27] Melero, S., Ruiz Porras, J. C., Herencia, J. F., Madejón, E. (2006): Chemical and biochemical properties in a silty loam soil under conventional and organic management. Soil. Till. Res. 90: 162-170.

[28] Mrówczyński, M., Roth, M. (2009): Sustainable application of plant protection chemicals. - Problemy Inżynierii Rolniczej 2: 93-97.

[29] Piotrowska, A., Długosz, J., Zamorski, R., Bogdanowicz, P. (2010): Changes of enzymatic activity in soil supplemented with microbiological preparation UGmax. World Congress of Soil Science. Soil Solutions for a Changing World. 1-6 August Brisbane, Australia: 5-8.

[30] Piotrowska, A., Długosz, J., Zamorski, R., Bogdanowicz, P. (2012): Changes in some biological and chemical properties of an arable soil treated with the microbial biofertilizer UGmax. - Pol. J. Environ. Stud. 21(2): 455-463.

[31] Puła, J., Skowera, B. (2004): Quality properties variability of potato tubers of Mila variety cultivated on light soil depending upon weather conditions. - Acta Agrophys. 3(2): 359-366.

[32] Ratajczak, K., Sulewska, H., Szymańska, G., Wolna-Maruwka, A., Faligowska, A. (2016): The effect of soil type and soil additives on the selected growth parameters and yield of flowerheads of Calendula officinalis L. - Herba Pol. 62(2): 17-30.

[33] Roztropowicz, S. (1999): Methods of Observation, Measurements and Sampling in Agricultural Experiments in Potatoes. - Ed. Plant Breed. Aclim. Inst., Sect., Jadwisin.

[34] Rutkowska, U. (1981): Selected methods of study composition and nutritive value of food product. - Ed. PZWL Warszawa.

[35] Sawicka, B. (2000): The influence of production technology on potato tuber quality. Pamiętnik Puławski 120: 391-401.

[36] Sawicka, B., Pszczółkowski, P. (2005): Dry matter and carbohydrates content in the tubers of very early potato varieties cultivated under coverage. Acta Sci. Pol., Hortorum Cultus 4(2): 111-122.

[37] Sawicka, B., Mikos-Bielak, M. (2008): Modification of potato tuber chemical composition by applications of the Asahi SL biostimulator. - In: Dąbrowski, Z. T. (ed.) Biostimulators in modern agriculture: Solanaceous crops. Editorial House Wieś Jutra, Warszawa.

[38] Sawicka, B., Michałek, W., Pszczółkowski, P. (2015): The relationship of potato tubers chemical composition with selected physiological indicators. - Zemdirbyste-Agriculture 102(1): 41-50.

[39] Sulewska, H., Szymańska, G., Pecio, A. (2009): Evaluation of UGmax soil additive applied in maize grown for grain and silage. - J. Res. Appl. Agric. Engin. 54(4): 120-125.

[40] Szewczuk, C., Sugier, D., Baran, S., Bielińska, E. J., Gruszczyk, M. (2016): The impact of fertilising agents and different doses of fertilizers on selected soil chemical properties as well as the yield and quality traits of potato tubers. - Annales UMCS 71(2): 65-79.

[41] Trawczyński, C., Bogdanowicz, P. (2007): Utilization of soil fertilizer in ecological aspect of potato cultivation. - J. Res. Appl. Agric. Engin. 52(4): 94-97.

[42] Trawczyński, C., Prokop, W. (2016): Yield and quality of potato tubers as affected by fertilisation involving the use of soil-incorporated and foliar commercial fertilizer products. - Pol. J. Agron. 24: 23-29.

[43] Wegener, C. B., Jansen, G., Jürgens, H. U. (2015): Bioactive compounds in potatoes: Accumulation under drought stress conditions. - Functional Foods in Health and Disease 5(3): 108-116. 
[44] Wichrowska, D., Wszelaczyńska, E., Pobereżny, J. (2015): Effect of nutrient supply from different sources on some quality parameters of potato tubers. - J. Elem. 1: 217-230.

[45] Zarzecka, K., Gugała, M., Milewska, A. (2011): Effect of soil fertilizer UGmax on potato yielding and plant health. - Prog. Plant Prot. 51(1): 153-157.

[46] Zarzecka, K., Gugała, M., Zarzecka, M. (2013): Potato as good source nutrients. Postępy Fitoterapii 3: 191-194.

[47] Zarzecka, K., Gugała, M., Mystkowska, I., Sikorska, A. (2014): Influence of the soil conditioner UGmax on nitrogen, phosphorus and magnesium content in potato tubers. Acta Sci. Pol., Agricultura 13(2): 93-101. 